\title{
Vymedzenie noriem, prvopočiatky morálky a vzájomná dôvera ${ }^{1}$
}

\author{
Classification of norms, roots of morality and mutual trust
}

\author{
Miroslav Popper \\ Ústav výskumu sociálnej komunikácie \\ Slovenská akadémia vied \\ Dúbravská cesta 9, 84104 Bratislava 4 \\ popper@savba.sk
}

\begin{abstract}
Abstrakt/ Abstract
Príspevok pozostáva z troch častí. Prvá čast' sa zaoberá taxonómiou a kritériami klasifikácie rôznych druhov noriem. Poukazuje na to, že rozdiel medzi dvoma najdôležitejšími druhmi kooperačných noriem - sociálnymi a morálnymi - je skôr kvantitatívneho než kvalitatívneho charakteru a navrhuje trojdimenzionálny model ich diferenciácie. Druhá čast' je venovaná morálnym normám a zdôvodňuje dominantnú rolu emócií pre vznik a fungovanie morálky, ktorá zohráva kl’účovú rolu pri ochrane spoločnosti pred najnebezpečnejšími sociálnymi konfliktami. V tretej časti sa argumentuje, že vzájomná sociálna dôvera, nevyhnutná pre medzil'udskú kooperáciu, sa postupne vytvára zdola nahor, najskôr na úrovni najbližšej rodiny a postupne sa rozširuje na d'alšie okolie. Pre jej zvýšenie a udržanie sú nevyhnutné sociálne a morálne normy, ktoré tiež historicky vznikali najskôr v lokálnych spoločenstvách a až postupne sa šírili do širších sociálnych celkov. Príspevok upozorňuje na možné negatívne konzekvencie plynúce z podceňovania roly sociálnych a morálnych noriem a snahy riadit' sa namiesto nich len legislatívnymi normami, spočívajúce v oslabení sociálnych väzieb.
\end{abstract}

The paper consists of three parts. The first part deals with taxonomy and classification criteria of various kinds of norms. It points out that the difference between two most important cooperation norms - social and moral - has more quantitative than qualitative nature and suggests a threedimensional model of discrimination between them. The second part is devoted to moral norms. Dominant role of emotions in emergence and functioning of morality, which plays a key role in protecting society from most dangerous social conflicts, is justified. In the third part it is argued that gradual building of mutual social trust is a bottom-up process, starting at the level of closest family and then proceeding to further surroundings. For its increase and maintenance, the existence of social and moral norms, which historically emerged in local societies and gradually disseminated into broader social units, is inevitable. The paper notices potential negative consequences of weakening social bonds resulting from underestimation of the role of social and moral norms and from effort to follow solely the legal norms.

\footnotetext{
${ }^{1}$ Príspevok vznikol vd’aka podpore grantu VEGA: 2/0015/12.
} 


\section{Vymedzenie noriem}

Spoločenský život l'udí je nepredstavitel'ný bez toho, aby si vytvorili určité normy správania v rôznych situáciách a aby sa nimi následne riadili. Nesprávanie sa v súlade s očakávaniami iných, založené na rešpektovaní dohodnutých pravidiel, by viedlo k chaosu, nepredvídatel'nosti, neistote, nemožnosti koordinácie a kooperácie, teda k strate najdôležitejších atribútov sociálneho fungovania. Navyše individuálne porušovanie dohodnutých noriem v skupine vedie zväčša $\mathrm{k}$ výčitkám, trestom od iných členov a niekedy až k vylúčeniu previnilca z kolektívu. $\mathrm{V}$ tomto príspevku sú normy skúmané a analyzované z evolučnej perspektívy. Na najvšeobecnejšej úrovni sa dajú charakterizovat' ako správanie, ktoré sa bežne vyskytuje alebo ktoré je očakávané v určitej situácií a ktoré je možné vyjadrit' formou pravidiel typu: ak nastane situácia $X$ tak prebieha správanie $Y$ alebo ak nastane situácia X tak by malo prebiehat' správanie Y. Už z ich všeobecnej formulácie je zrejmé základné rozlíšenie noriem na dve kategórie a to deskriptívne a predpisové. Deskriptívne normy, ako už z ich názvu vyplýva, sú tie, ktoré opisujú určité bežné, typické, pravidelne sa vyskytujúce javy alebo udalosti. Napríklad, ak vonku mrzne, tak väčšina l'udí nosí čiapku alebo ak l'udia pozvú iných k sebe na návštevu, tak im zväčša ponúknu drobné občerstvenie. Ide teda o štatisticky často sa vyskytujúce správanie, ktoré však nemusí byt' nikým vynucované. Na rozdiel od deskriptívnych noriem sa predpisové normy vyznačujú tým, že už nielen opisujú, ale aj predpisujú, aké správanie je zakázané, prípustné a povinné. Tým nadobúdajú regulačnú aj kontrolnú funkciu. Ich súčastou je vynucujúci mechanizmus, ktorý zabezpečuje možnost' potrestania tých, ktorí ich porušia. V rámci tejto kategórie rozlišujeme štyri základné druhy noriem:

Konvencie, t.j. zaužívané formy správania, obyčaje, zvyklosti, ktorými sa l'udia riadia pri vykonávaní určitých činností (napríklad používanie príboru pri jedení v reštaurácií alebo zakrytie si úst pri zívaní).

Sociálne normy slúžia najmä na zabezpečenie reciprocity a kooperácie, ich úlohou je zaistit', aby sa l'udia nesnažili získat' zdroje (energetické, materiálne a iné) na úkor iných, aby sa nepodiel'ali na ziskoch bez toho aby na ne sami vynaložili primerané náklady.

Morálne normy sú zamerané predovšetkým na ochranu pred fyzickým alebo psychickým ubližovaním a na dodržiavanie základných l'udských práv a spravodlivosti.

Tieto tri druhy neformálnych noriem, ktoré vznikajú spontánne, sa používajú pri riešení takých spoločenských problémov, pre ktoré nie sú vytvorené a prijaté oficiálne právne zákony. Medzi sebou sa líšia najmä v miere závažnosti ich nedodržiavania. Kým porušenie konvencií zväčša nemá závažné dôsledky pre porušitel'a, nedodržanie sociálnych a morálnych noriem sa posudzuje ovel'a prísnejšie.

Legislatívne normy sa vyskytujú v zákonoch, smerniciach a nariadeniach a na rozdiel od predošlých troch druhov predpisových noriem sú formálne stanovené autoritou reprezentantmi štátu, pričom taxatívne sú vymedzené aj tresty za ich porušenie. 
Sociálne, morálne, aj legislatívne normy predovšetkým slúžia ako prevencia a regulácia konfliktov medzi dvoma alebo viacerými jedincami, usmerňujú myslenie, konanie aj prežívanie a zároveň sú nástrojom sociálnej kontroly nežiaduceho konania. Ich hlavným ciel'om je zabezpečit' kooperáciu, ochranu pred fyzickým alebo psychickým ubližovaním a čo najvyššiu mieru spravodlivosti.

Uvedená klasifikácia noriem má však svoje úskalia, hranice medzi jednotlivými druhmi noriem sú skôr neostré, než jasne určitel'né, čo dokumentujú aj odlišné až nesúrodé taxonómie vyskytujúce sa $\mathrm{v}$ relevantnej literatúre. Napríklad Bicchieriová ${ }^{2}$ rozlišuje $\mathrm{z}$ hl'adiska funkcie (a) deskriptívne normy (napr. móda), ktorých ciel’om je koordinácia alebo imitácia iných, (b) konvencie ako deskriptívne normy, ktoré odolali istej skúške času (napr. pravidlá spoločenskej etikety, pravidlá cestnej premávky) a (c) sociálne normy riešiace situácie, v ktorých by jedinec mohol uprednostnit’ krátkodobé alebo úzko zamerané osobné záujmy pred kooperáciou alebo reciprocitou, t.j. situácie, v ktorých je ohrozená možnost' spoločného zisku, ked' v bezprostrednom záujme jedinca nemusí byt' správat' sa sociálne prospešným spôsobom. Konvencie zarad’uje medzi deskriptívne normy, avšak ked’že ich dodržiavanie môže byt' aj vynucované, je zmysluplnejšie začlenit' ich skôr do predpisových noriem.

Ullmann-Margalitová ${ }^{3}$ okrem koordinačných a kooperačných noriem rozlišuje aj normy, ktorých ciel'om je udržat' status quo nerovnosti privilegovanou skupinou. Tento posledný druh protirečí všeobecnej predstave, že sociálne normy zabezpečujú, aby človek prihliadal nielen na vlastné záujmy, ale aj na záujmy a potreby kohokol'vek iného. Privilegovaná skupina môže byt' menšinová (rôzne mocenské elity), ale aj väčšinová (diskriminujúca rôzne etnické, sociálne znevýhodnené alebo handicapované skupiny).

Pravidlá cestnej premávky sú zaujímavým príkladom, ktorý zd’aleka nemožno tak jednoznačne zaradit' ku konvenciám, ako to robí Bicchieriová ${ }^{4}$. Na jednej strane je pravda, že napríklad dohoda o tom, či budeme jazdit' po l'avej alebo pravej strane cesty je vel'mi užitočná konvencia zabraňujúca množstvu dopravných nehôd. Pre všetkých je rovnako výhodná a nikoho neobmedzuje, takže nie je dôvod, aby nebola dodržiavaná. Na strane druhej, porušovanie takých pravidiel cestnej premávky, ako prekračovanie rýchlosti patrí medzi legislatívne normy. Tie sú stanovené autoritami reprezentujúcimi štát, pričom t'ažko možno predpokladat', že neustále obmedzovanie rýchlosti by vzniklo na základe konvencie. Dôvod je ten, že aj ked' experti tvrdia, že vd’aka rýchlostným limitom sa znižuje počet havárií, táto argumentácia dotiahnutá ad absurdum by znamenala, že najbezpečnejšie by bolo, ak by autá jazdili maximálne rýchlost'ou $10 \mathrm{~km}$ za hodinu, prípadne úplne stáli na mieste. Inými slovami, autá by stratili zmysel. Preto nie je dôvod očakávat', že len na základe konvencií by si šoféri neustále dobrovol'ne znižovali maximálne povolenú rýchlost'. Naopak, zapríčinenie vážnej havárie pod vplyvom návykových omamných látok nie je len porušením legislatívnych, ale aj

\footnotetext{
${ }^{2}$ Bicchieri (2006).

${ }^{3}$ Ullmann-Margalit (1997).

${ }^{4}$ Bicchieri (2006).
} 
morálnych noriem. Tieto ilustrácie poukazujú na problematickost' jednoznačne zaradit' určité formy správania k tým-ktorým normám, ako aj na to, že hranice medzi jednotlivými druhmi noriem sú často rozmazané či hmlisté. Navyše, niektoré neformálne vzniknuté normy môžu byt' v pôvodnej alebo modifikovanej podobe oficiálne uzákonené, kým iné sa môže snažit' štát eliminovat'. Príkladov dokumentujúcich nejednoznačnost' taxonómie noriem je množstvo a najdôležitejšie z nich budú d'alej analyzované.

V relevantnej literatúre vychádzajúcej z evolučného prístupu sa rozlišuje najmä medzi konvenciami a morálnymi normami, pričom morálne normy ${ }^{5}$ sú vo všeobecnosti považované za najrýdzejšie, najdôležitejšie a najdominantnejšie. Ich exkluzívnost' spočíva v predpoklade, že akonáhle sú už raz osvojené, stávajú sa takmer nezávislé od stanoviska iných osôb, či inštitúcii alebo pravidiel. Napríklad Turiel ${ }^{6}$ odlišuje morálne normy od konvenčných noriem tým, že sú nezávislé na pravidlách, autorite, spoločnej praxi a dohodách. Podobne aj Hauser ${ }^{7}$ zdôrazňuje, že kým pri sociálnych normách a konvenciách je dôležité stanovisko autority (napr. či je možné jest' v jedálni rukami), na porušenie morálky (napríklad, že je v poriadku, ak sa milenci podvádzajú) nám nemôže dat' mandát žiadna autorita.

Aj bežní l'udia benevolentnejšie hodnotia nedodržanie konvenčných než morálnych noriem a pri posudzovaní prekročenia konvenčných noriem považujú za dôležité znalosti o lokálnych pravidlách a tiež stanovisko autority (Hauser ${ }^{8}$, Mallon \& Nichols ${ }^{9}$ ). Ako ilustratívny príklad uvádzajú $^{10}$, že pokial' na škole učitel' nezavedie pravidlo, že počas vyučovania sa nesmie žuvat' žuvačka, žiaci nebudú považovat' jej žuvanie za nesprávne, ale aj pokial' na škole nebude zavedené pravidlo o neprípustnosti fackania sa spolužiakov, budú deti posudzovat' takéto správanie ako nesprávne. Teda ani lokálne pravidlá, ani stanovisko autority nedávajú mandát na porušenie morálnych noriem. Avšak aj tieto kritéria delenia noriem sú problematické.

Hoci Prinz ${ }^{11}$ súhlasí s názormi viacerých autorov (napr. Turiel ${ }^{12}$, Nucci ${ }^{13}$ ), že vo všetkých kultúrach l’udia rozlišujú medzi morálnymi a konvenčnými pravidlami, nesúhlasí $\mathrm{s}$ troma definujúcimi charakteristikami, z ktorých vychádzajú pri odlišovaní týchto dvoch druhov noriem. Konkrétne, nesúhlasí s predpokladom, že morálne pravidlá sú oproti konvenčným považované za závažnejšie, posudzované podl'a zhubných dôsledkov na obet'

\footnotetext{
${ }^{5}$ Príspevok nemá snahu venovat’ sa nadprirodzeným vysvetleniam či zdôvodneniam vzniku morálnych noriem.

${ }^{6}$ Turiel (2006).

${ }^{7}$ Hauser (2006).

${ }^{8}$ Tamtiež.

${ }^{9}$ Mallon \& Nichols (2010).

${ }^{10}$ Tamtiež.

${ }^{11}$ Prinz (2008).

${ }^{12}$ Turiel (2002).

${ }^{13}$ Nucci (2001).
} 
a chápané ako objektívne pravdivé, t.j. nezávislé od toho, čo si niekto iný o nich myslí. Uvádza nasledujúce príklady. Čo sa týka závažnosti, aj ked’ je morálne zlé zjest’ posledný keksík v dome bez spýtania sa ostatných členov, či z neho kúsok nechcú, nie je to extrémne zlé. Naproti tomu je mimoriadne zlé íst' do práce nahý, aj ked' obliekanie je len sociálnou konvenciou. Pokial' sa jedná o ublíženie, skarifikácia (narezanie povrchu kože) (alebo tiež tetovanie, piercing) je skutočne bolestivé, avšak averzia voči tomu sa považuje skôr za osobnú preferenciu než za dôvod morálneho odsúdenia. Odvolávajúc sa na Haidta et. al. ${ }^{14}$ ukazuje, že naopak, niektorí l'udia považujú určité skutky za morálne neakceptovatel'né, aj ked' nie sú ubližujúce - napr. umývanie toalety národnou zástavou. A pokial’ sa jedná o autoritu, tvrdí, že mnohé pravidlá sú nezávislé na autorite a pritom nie sú morálne, ako napr. nejedenie rozkladajúceho sa mäsa a iné sú závislé na autorite a morálne, ako napr. zákazy konzumácie istých druhov jedál (napr. hovädzie mäso v Indii). Z toho podl'a Prinza vyplýva, že rozdiel medzi morálnymi a konvenčnými normami je neraz nejasný, či rozmazaný. Argumentuje, že pravidlá správania môžu mat' vo všeobecnosti aj morálnu aj konvenčnú zložku. Preto rozlišovanie medzi morálnym a konvenčným nepovažuje za rozdiel medzi dvoma druhmi pravidiel, ale za rozdiel medzi zložkami pravidiel.

Aj ked' Prinz zretel'ne poukazuje na problematickost' kritérií klasifikácie noriem, niektoré jeho príklady sú pomerne zavádzajúce. Napríklad obliekanie sa je síce konvenciou v tom zmysle, že sa pri rôznych príležitostiach očakáva „,vhodný“ typ šiat, avšak nahota je úplne iná kvalitatívna kategória, ktorá s touto konvenciou nesúvisí. Nahota na verejných priestranstvách (okrem špecificky vyhradených, ako napr. pláže pre nudistov) je aj morálnym, aj legislatívne postihnutel'ným prehreškom. Jeho d’alší príklad týkajúci sa konzumácie hovädzieho mäsa je závislý na božskej autorite, čo je zas kvalitatívne úplne iná kategória autority, než sa vyžaduje pri konvenčných normách. Pod vonkajšou autoritou sa totiž rozumie stanovisko l'udských jedincov, ktorí majú v situácií porušenia konvenčných noriem istý vplyv.

Ďalší problém spôsobuje rozlíšenie sociálnych a morálnych noriem. Tie sú si relatívne najpodobnejšie, ked’že sú nielen predpisové, ale zároveň sa uplatňujú v ovel'a dôležitejších l'udských sociálnych činnostiach a aktivitách než konvencie a riadenie sa nimi často nie je v súlade s krátkodobými ciel'mi a záujmami jedinca. Uplatňujú sa najmä v takých sférach, ako je zvyšovanie vzájomnej dôvery, reciprocita, kooperácia, znižovanie podvádzania, klamstva, ubližovania a tiež zabezpečenia ochrany voči deviantom, bezpečia, istoty, vzájomnej pomoci a spravodlivosti. Preto sa im budem d'alej podrobne venovat'. Avšak aj vich prípade je problematické jasne a zretel'ne ich operacionalizovat'. V závere tejto časti navrhujem trojdimenzionálny model diferencujúci sociálne a morálne normy.

Výstižným prototypom mnohých definícii sociálnych noriem je definícia Fehra a Gächtera ${ }^{15}$, podla ktorej je sociálna norma: (1) pravidelnost' v správaní, ktoré je (2) založené na sociálne zdiel'anom presvedčení ako by sa mal niekto správat', ktoré aktivuje (3) vynútenie predpísaného správania pomocou neformálnych sociálnych sankcií.

\footnotetext{
${ }^{14}$ Haidt et al. (1993).

${ }^{15}$ Fehr \& Gächter (2000).
} 
Bicchieriová ${ }^{16}$ podrobnejšie vymedzuje podmienky existencie sociálnych noriem:

Jedinec vie o existencii pravidla, ktoré je platné v danej situácii (kontingencia)

Jedinec preferuje konat' podl'a tohto pravidla $\mathrm{v}$ danej situácii za podmienok že (podmienečná preferencia):

verí, že dostatočne vel'ká podmnožina populácie sa riadi daným pravidlom v danej situácii (empirické očakávanie) a zároveň bud’

verí, že dostatočne vel'ká podmnožina populácie od neho očakáva, že sa bude riadit' daným pravidlom v danej situácii (normatívne očakávanie) alebo

verí, že dostatočne vel'ká podmnožina populácie od neho očakáva, že sa bude riadit' daným pravidlom $\mathrm{v}$ danej situácii a môže sankcionovat' jeho správanie (normatívne očakávanie so sankciami).

Uvádza ${ }^{17}$ tiež dôvody dodržiavania sociálnych noriem, a to:

1. strach z dôsledkov porušenia, t.j. motivácia vyhnút' sa negatívnym sankciám

2. túžba potešit' iných, t.j. motivácia dosiahnutia pozitívnej odmeny

3. akceptácia normatívnych očakávaní ako opodstatnených či odôvodnených (norme môžu byt' prisúdené pozitívne hodnoty).

Ak je rozhodujúcou motiváciou dodržiavania noriem vyhnút' sa trestu, vtedy je existencia vonkajších sankcií dôležitá. Naopak, v prípade stotožnenia sa s normou a prisúdenia jej vysokej hodnoty vonkajšie sankcie nie sú potrebné. Niekedy tiež dochádza k dynamickým zmenám $\mathrm{v}$ dôvodoch dodržiavania sociálnych noriem, čo Bicchieriová ilustruje na príklade fajčenia. Fajčiar môže prestat' fajčit' najprv na rôznych miestach kvôli sankciám a neskôr si zvnútorní nefajčenie ako cnost' spojenú s prevenciou onkologických a srdcocievnych chorôb a žiadne vonkajšie sankcie už nepotrebuje.

Z hl'adiska odlíšenia sociálnych noriem od morálnych je pre Bicchierovú ${ }^{18}$ dôležitá podmienečná preferencia. Zdôrazňuje, že pri riadení sa morálnymi normami je rozhodujúca nepodmienečná preferencia a nepodmienečný záväzok, t.j. že očakávania iných l’udí o podrobení sa morálnym normám nie sú dobrým dôvodom na ich dodržiavanie. Predpokladá tiež, že morálne normy môžu mat' evolučný pôvod, ked’že uvažovanie o zabití alebo inceste bežne vyvolá silné negatívne emócie a odpor.

Toto odlišovacie kritérium však samo o sebe nie je postačujúce a zároveň je problematické. Aj morálne normy museli byt' spoluvytvárané aj vplyvmi vonkajšieho prostredia a kultúry. Navyše, minimálne od čias Milgramových experimentov ${ }^{19}$ skúmajúcich množstvo (fiktívnej) bolesti, ktoré dokáže spôsobit’ bežný človek inej osobe, ak je k tomu

\footnotetext{
${ }^{16}$ Bicchieri (2006, s. 11).

${ }^{17}$ Tamtiež.

${ }^{18}$ Tamtiež.

${ }^{19}$ Milgram (1963).
} 
pobádaný experimentátorom, je zrejmé, ako l'ahko sa v istých situáciách väčšina l’udí naprieč kultúrami, pohlaviu, vzdelaniu a veku - dokáže vzdat' vlastnej morálnej zodpovednosti, presunút' ju na plecia autority.

Čo sa týka negatívnych emócií, tie, aj ked’ zrejme v menšej miere, dokáže vyvolat’ aj porušenie sociálnych noriem (napr. netriedenie odpadu v ekologicky zmýšl'ajúcej skupine), dokonca aj porušenie konvencií (napr. príchod študenta na štátnice v monterkách).

Dubreuil a Grégoire ${ }^{20}$ kritizujú Bicchieriovej rozlíšenie sociálnych a morálnych noriem len podl'a kritéria podmienečnej preferencie z iného dôvodu. Argumentujú, že motivácia dodržiavat' sociálne normy môže byt' zároveň ovplyvnená aj sociálnym kontextom a zároveň byt' skutočná (neinštrumentálna), teda nezávislá od želaní či očakávaní iných. Navrhujú integrovaný prístup k sociálnym normám, ktorý by bral do úvahy aj obsah normy, aj normatívne a empirické očakávania a ich vplyv na emočné procesy pri porušení noriem.

Idea zvažovat' aj obsah ako jedno z kritérií klasifikácie noriem nie je nová a najmä morálne normy sú charakteristické z hl'adiska obsahu tým, že ich ciel’om je chránit' (prípadne zlepšit') život l'udí a jeho kvalitu, so snahou zabránit' bolesti a utrpeniu (niekedy aj za cenu vlastného obetovania sa). De Waal ${ }^{21}$ je napríklad presvedčený, že morálka sa týka len dvoch oblastí konania, ktoré sú navzájom previazané, a to pomáhajúceho a neubližujúceho. Previazané sú preto, lebo ak je niekto v núdzi, ohrození života, trpí a druhý mu nepomôže, tak mu tým vlastne ubližuje. Tieto dve oblasti konania sa zároveň dominantne týkajú potrieb súvisiacich s prežitím a rozmnožovaním, čo sú vlastne univerzálne ultimátne evolučné príčiny správania. Viaceré štúdie (napr. Haidt ${ }^{22}$ ) však zároveň naznačujú, že obsah morálnych noriem, ktorý je výrazne kultúrne podmienený, sa môže týkat' aj iných oblastí, ktoré sú z hl'adiska spoločenského usporiadania považované za dôležité. Spolupodmienenost' morálnych noriem spoločenským prostredím spochybňuje predpoklad o ich univerzálnosti. Zároveň však takmer vo všetkých kultúrach a historických obdobiach vyvolávali určité spôsoby konania u väčšiny l’udí vel'mi silné negatívne emócie. Typickým príkladom je ubližovanie niekomu bezbrannému bez príčiny. Silné ubližženie teda zohráva dôležitú, no nie dostatočnú úlohu pri diferenciácií sociálnych a morálnych noriem.

Ked’že obsah morálnych noriem môže byt' do istej miery kultúrne špecifický, nedá sa taxatívne vymenovat', aké konkrétne predpisy konania by spadali medzi ne. Skôr je možné pokúsit' sa odlísit' normy podl'a intenzity negatívnych emócií, ktoré vyvolá ich porušenie. Teda, nech sa jedná o l’ubovol'ný obsah, pokial' v danej kultúre vyvolá jeho porušenie silné negatívne emócie, norma, ktorá bola porušená, by mala patrit’ skôr medzi morálne normy.

Pri zohl'adňovaní uvedených kritérií by sa dalo uvažovat' o trojdimenzionálnom modeli, ktorý by odlišil morálne a sociálne normy. Tri navzájom previazané dimenzie $\mathrm{v}$ ňom vyjadrujú mieru: ublíženia, závislosti od očakávaní iných (vrátane vonkajšej autority)

\footnotetext{
${ }^{20}$ Debreuil a Grégoire (2013).

${ }^{21}$ De Waal (2006a).

${ }^{22}$ Haidt (2013).
} 
a negatívne vzbudených emócií (pozri obr. č. 1).

Obr. č. 1: Trojdimenzionálny model diferencujúci sociálne a morálne normy

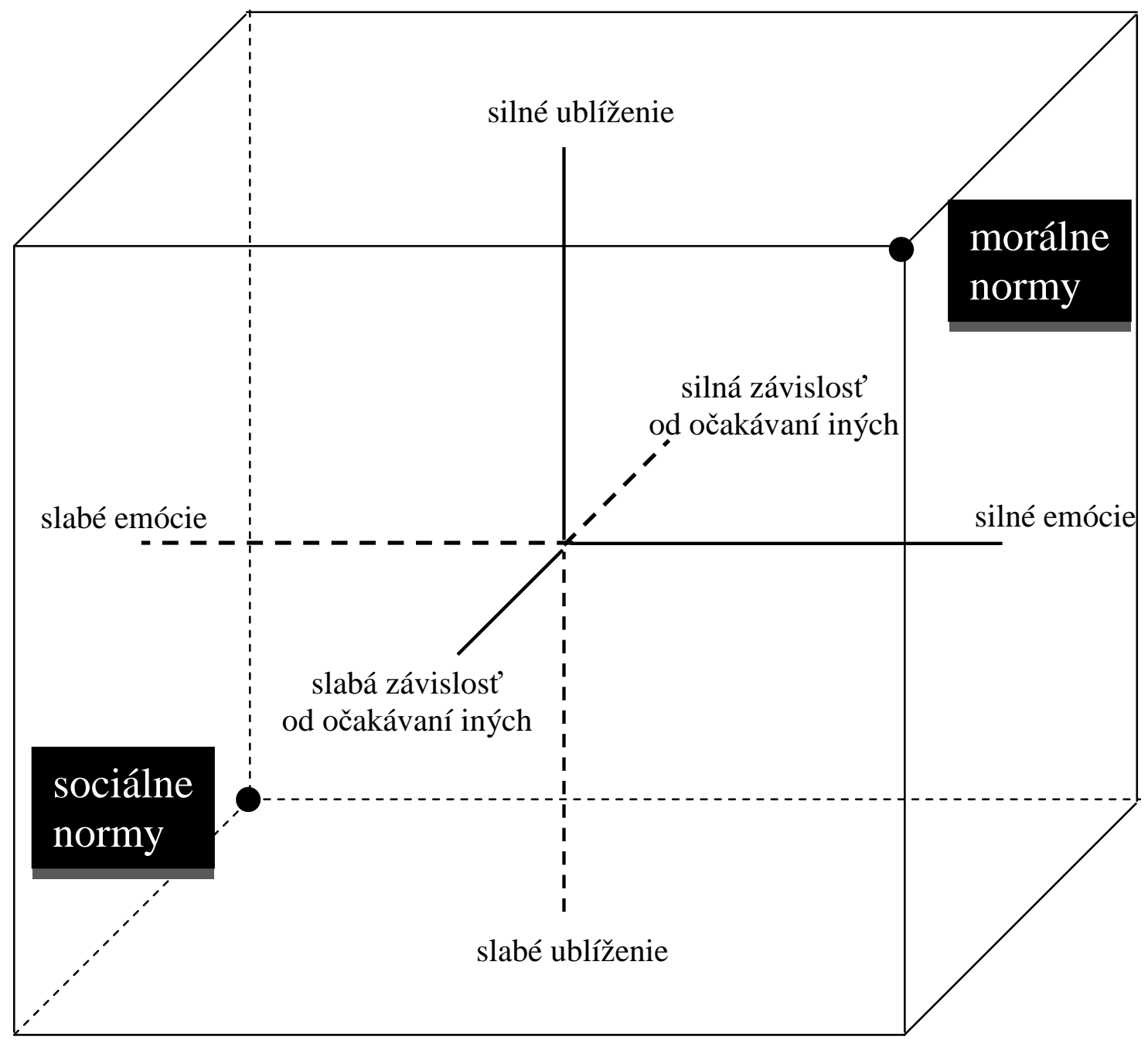

Uvedený model umožňuje základnú dištinkciu medzi sociálnymi a morálnymi normami, ktorej hlavný význam spočíva v tom, že morálne normy sú t’ažšie relativizovatel'né. Teda, kým sociálne normy sú skôr záležitost’ou (lokálnej dohody), ktorú je možné l'ahšie spochybnit', či prispôsobit' meniacim sa okolnostiam, porušenie už raz osvojených morálnych noriem nie je oprávnené ani v prípade dosiahnutia lokálneho konsenzu. Navyše tento model ukazuje, že rozdiely medzi sociálnymi a morálnymi normami nemajú kvalitatívnu, ale skôr kvantitatívnu povahu. Berie tak do úvahy rozdiely medzi odlišnými kultúrami, ktoré môžu to 
isté konkrétne správanie považovat' za spadajúce alebo nespadajúce do oblasti morálky. Zároveň pre zaradenie normy medzi morálnu alebo sociálnu nie je nevyhnutné dosiahnut' vysokú alebo nízku hodnotu vo všetkých troch dimenziách simultánne. Postačujúce je, ak sú aspoň v dvoch dimenziách splnené kritériá pre sociálne alebo morálne normy. Teda napríklad, ak nejaké neakceptovatel'né konanie nespôsobuje nikomu silné ublíženie, ale napriek tomu vzbudzuje silné negatívne emócie bez ohl'adu na očakávania iných, možno ho zaradit' medzi morálne nesprávne.

Aplikáciu modelu možno ilustrovat' na konkrétnych príkladoch. Uvažujme o mučení nevinného človeka. Pri takomto skutku dochádza k silnému ubliženiu obete, vyvoláva to v nás vel'mi silné negatívne emócie voči konatel'ovi skutku a aj v prípade, ak by sa nejaká skupina l'udí dohodla, že takéto správanie je v poriadku, budeme ho považovat' za neprijatel'né. Na základe všetkých troch dimenzií možno dané správanie považovat' za morálne neakceptovatel'né. Podobným, jasne kategorizovatel'ným príkladom do skupiny morálnych noriem môže byt' zanedbávanie starostlivosti o maloleté diet’a jeho opatrovatel'mi (rodičmi). $\mathrm{Na}$ druhej strane nezaplatenie prepitného v reštaurácií v západných kultúrach, v ktorých sa prepitné očakáva, nespôsobuje vel'ké ublíženie obsluhujúcemu personálu a nevyvoláva vel'mi silné negatívne emócie. Dokonca aj v prípade silného rozhorčenia čašníka by d’alšie dve dimenzie stále dané správanie usmerňovali medzi sociálne normy. Navyše, v mnohých východných kultúrach sa prepitné ani neočakáva, čo poukazuje na obmedzenú platnost' tejto lokálnej (západnej) sociálne normy. Doteraz uvedené príklady boli pomerne jednoznačne začlenitel'né a preto teraz prejdime $\mathrm{k}$ ambivalentnejším situáciám. Umývanie toalety národnou zástavou vlastnej krajiny síce nespôsobuje nikomu ublíženie, ale ak bez ohl’adu na očakávania iných vyvolá silné negatívne emócie, možno takéto konanie zaradit' skôr k morálnemu priestupku. Naproti tomu nadmerný lov rýb, t.j. nedodržanie stanovených kvót môže síce vyvolávat' silné negatívne emócie, ale nespôsobuje bezprostredné silné ublíženie a a je silne závislé od očakávaní iných a preto patrí skôr medzi sociálne normy. Uvedené príklady ilustrujú, že povaha morálnych noriem sa od povahy sociálnych noriem líši predovšetkým v kvantitatívnych ukazovatel'och, pričom pre zaradenie normy medzi sociálne alebo morálne je postačujúce dosiahnutie vysokých alebo nízkych hodnôt v l'ubovol'ných dvoch dimenziách modelu.

\section{Prvopočiatky morálky}

Morálne normy, ktoré sú súčast'ou nášho života desat'tisíce až státisíce rokov, sú v porovnaní s inými normami najstabilnejšie a najuniverzálnejšie. Ich dodržiavanie bolo pre prežitie členov skupiny natol'ko dôležité, že evolúcia nás vybavila silnými emočnými reakciami, ktoré sa spontánne navodia, ked' sme svedkami ich porušovania. Haidt a Bjorklund ${ }^{23}$ na základe množstva empirických zistení tvrdia, že v každej spoločnosti a dokonca aj u iných živočíšnych druhov sa vyskytujú a automaticky „spúšt’ajú“ emočné reakcie v situáciách, ktoré sú spojené s: ubližením/starostlivost'ou (napr. citlivost' a/alebo nechut' k prejavom bolesti

\footnotetext{
${ }^{23}$ Haidt a Bjorklund (2008).
} 
a utrpenia iných, najmä mladých a zranitel'ných), férovostou/reciprocitou (napr. negatívne reakcie na tých, ktorí neoplatia láskavost'), autoritou/rešpektom (napr. hnev voči tým, ktorí neprejavia patričné znaky úcty a rešpektu). Podobne aj Rozin et al. ${ }^{24}$ dospeli na základe výsledkov experimentov k záveru, že tri (morálne) emócie - hnev, pohŕdanie a hnus sú naprieč kultúrami vyvolávané pri porušení sociálneho poriadku inými (aj ked’ sa nás osobne dôsledky toho priamo netýkajú).

Opät' však treba zdôraznit', že aj ked' morálne normy možno považovat' za univerzálnejšie ako iné pravidlá, napríklad v každej kultúre je zavraždenie (minimálne niektorých členov spoločnosti) považované za nemorálne, neznamená to, že sú, na rozdiel od sociálnych noriem, úplne sociálne nepodmienené. Napríklad v čase vojny je zabitie nepriatel'a považované nielen za správne, ale aj za nevyhnutné či želatel’né správanie.

Podl’a Prinza $^{25}$ sú morálne normy vlastne sentimentálnymi normami, ked’že potvrdzujú či podporujú rôzne sentimenty (pocity). Prinz (v súlade s britskými moralistami) tvrdí, že morálne normy sú zakotvené v morálnych emóciách, v tom zmysle, že vyjadrujú naše sentimenty. Podrobnejšie špecifikuje podmienky fungovania emócií, aby sme normy mohli uznat' za morálne: Za prvé musia zahrňovat', respektíve vyvolat' dva druhy emócií, zamerané na seba aj na druhých. Ako dôvod uvádza, že môžem pocit'ovat' zhnusenie, ked' vidím otvorenú krvácajúcu ranu priatel'a po úraze, ale ked' sa to stane mne, necítim hanbu alebo vinu. Druhou podmienkou je, že naše emócie musia byt' zamerané [aj] na tretiu stranu, teda týkajú sa aj situácií, do ktorých nie sme priamo zaangažovaní. A za tretie sa pri zrelých morálnych úsudkoch nevyhnutne prejavujú aj meta-emócie. T.j. ak sa človek, ktorý niečo zlé urobí necíti vinný, druhí naňho budú nahnevaní nielen kvôli tomu, čo urobil, ale aj preto, lebo necíti l'útost' (nemá výčitky svedomia). Prinz ${ }^{26}$ uvádza tri línie dôkazov, prečo sú morálne normy sentimentálnymi:

Empirické zistenia, že morálne úsudky môžu byt' zmenené vplyvom sugescie, ktorej účinok v post hypnotickom stave dokáže vyvolat' emócie aj pri hodnotovo neutrálnych pojmoch.

Psychopati majú deficit negatívnych emócií a zároveň majú problém porozumiet' morálnym normám a odlíšit' ich od konvencií.

Na tesný vzt’ah medzi emóciami a morálnymi úsudkami možno usudzovat' aj z toho, že človek, ktorý je na niekoho nahnevaný kvôli skutku, ktorý spáchal, by sa cítil vinný aj ak by sám vykonal tento skutok. Preto verí, že daná skutok je morálne zlý.

$\mathrm{Na}$ dôležitost' emócií v súvislosti s morálnym rozhodovaním upozorňuje aj $\mathrm{Wright}^{27}$

\footnotetext{
${ }^{24}$ Rozin et al. (1999).

${ }^{25}$ Prinz (2008).

${ }^{26}$ Tamtiež.

${ }^{27}$ Wright (2006).
} 
tvrdením, že podl'a evolučnej psychológie boli l'udské emócie „dizajnované“ prírodným výberom, ako sprostredkovatelia alebo zástupcovia strategických kalkulácií, t.j. bud’ u našich predkov predchádzali vedomým strategickým kalkuláciám alebo ich nahrádzali. Navyše je emocionálne riadenie správania evolučne staršie než vedomé strategické riadenie správania a jeho výskyt možno podl'a neho pozorovat' aj u primátov.

Uvedené argumenty, ktoré sú podopreté nielen teoreticky - najmä evolučnou perspektívou, ale aj empirickými zisteniami psychológie a neurovied, hovoria v prospech primárnej úlohy emócií (a nie kognícií) ako podmienky konštituovania morálnych noriem. Tieto emócie boli adaptívne, pretože umožňovali vytváranie väčšej kooperácie a zároveň aj dokonalejšej možnosti ochrany voči agresorom.

Aj antropológ Boehm ${ }^{28}$ na základe metódy triangulácie predpokladá, že už spoločný predok l’udí, šimpanzov a bonobov žil v hierarchických skupinách a snažil sa v nich tlmit' konflikty prejavovaním útechy, zmierovania a aktívnym pacifikovaním. Ked’že raní l’udia žili v rovnostárskych tlupách, najpravdepodobnejším kandidátom na správanie, ktoré bolo prvý krát opísané ako deviantné, je podl'a neho tyranské správanie, kedy chce jedinec nadmieru dominovat' nad ostatnými a uplatňuje násilie, ktorým porušuje egalitárstvo. Sociálna kontrola spočíva vo vytvorení koalícií voči takýmto násilníkom za účelom ich potrestania, pričom politické a mocenské koalície možno podl'a neho nájst' už medzi primátmi. Domnieva sa, že morálne komunity univerzálne vznikli v dôsledku skupinového úsilia redukovat' bratrovražedný konflikt a snahe vyhnút' sa neprimerane vel'kej sút'aživosti, dominancii a viktimizácii. Súčasné egalitárske tlupy, podobne ako egalitársky založené kočovné tlupy lovcov-zberačov (predchádzajúce kmeňovému usadlému spôsobu života väčších hierarchicky založených skupín) sa podl’a neho vyznačujú kontrolou toho, aby sa jedinci nesprávali tyransky, t. j.: nepodvádzali a nevyhýbali sa kooperatívnemu úsiliu, neuchyl'ovali sa $\mathrm{k}$ vážnym klamstvám a krádežiam, cudzoložstvu, incestu a znásilneniu. Akonáhle sa takéto aktívne intervencie stali kolektívnymi nástrojmi sociálnej kontroly na potláčanie konfliktov a hned' ako jazyk umožnil pomenovat' správanie, ktoré je zakázané, mohla sa začat' plne rozvíjat' morálka ${ }^{29}$.

Kultúrny antropológ Knauft ${ }^{30}$ sa snaží rozšírit’ dôvody vedúce k nevyhnutnosti vzniku morálky. Okrem snahy o eliminovanie tyranského správania a podpory rovnostárstva zahŕna do prvopočiatkov evolúcie l’udskej morálky aj d’alšie črty, ako: obmedzenia sexuálneho správania, elementárne rozdelenie práce, socializovaná kontrola mladých mužov (samcov), rozrastajúca sa vel'kost' skupiny a tiež aj rastúca vel'kost' domova.

Boehm aj Knauft zdôrazňujú, že s nástupom jazyka potom bolo možné pomenovat' zakázané správanie a rozpracovat' pravidlá tvoriace symbolickú dimenziu morálky. Jazyk je aj hlavný diferencujúcim kritériom medzi plnohodnotnou l’udskou morálkou a protomorálkou,

\footnotetext{
${ }^{28}$ Boehm (2002).

${ }^{29}$ Tamtiež.

${ }^{30}$ Knauft (2002).
} 
ktorá sa vyskytuje u našich najbližších príbuzných živočíšnych druhov. Slovami Knaufta: „Internalizácia morálnych pravidiel v zhode s kultúrne predpísanými normami je charakteristická črta l’udskej morálky do značnej miery chýbajúca u non-l'udských primátov،31.

Aj ked' nie je žiadny dôvod voči takémuto odlíšeniu l'udskej a non-l'udskej morálky niečo namietat', z evolučného hl'adiska je dôležité, že je v biologickom záujme sociálne žijúcich druhov, v rámci ktorých je človek najsociálnejší živočích, aby sa pravidlá morálky vyvinuli a dodržiavali. Ako hovorí De Waal:

„Ak je teda sociálny život založený na spoločenskej zmluve, nie je to zmluva navrhnutá a podpísaná jednotlivými l’ud'mi, ale Matkou Prírodou. A ona ju podpíše len vtedy, ak reprodukčná zdatnost' narastá združovaním sa s ostatnými, čiže ked' sociálne žijúci jedinci zanechajú viac potomkov než solitérne žijúci jedinci. Tendencia združovat' sa teda nevznikla rozumovou vol'bou, ale genetickou matematikou. ... Nikto si nemusí vedome volit’ sociálny život““. ${ }^{32}$

Možno teda zhrnút', že evolúcia nás vybavila emóciami, ktoré vel'mi intenzívne pocit’ujeme v situáciách súvisiacich najmä so závažným ublížením. V snahe vyhnút' sa najvážnejší možným sociálnym konfliktom bolo potrebné zabezpečit' sociálnu kontrolu nad jedincami, ktorí ohrozovali ostatných členov spoločnosti. S nástupom jazyka sa jednotlivé pravidlá (ich obsahy), spolu so sankciami, hroziacimi za ich porušenie, dali formulovat' a najdôležitejšie z nich si l’udia zároveň aj internalizovali a následne sa nimi riadili aj bez ohl'adu na názor autority. Opät' vidíme, ako sú morálne normy sýtené dimenziami, navrhnutými vyššie v rámci trojdimenzionálneho modelu (obr. č.1). Zavedenie a používanie noriem teda zásadným spôsobom ul’ahčuje sociálne fungovanie l’udskej spoločnosti.

\section{Vzájomná dôvera}

Spolupráca je t’ažko predstavitel'ná bez určitej miery vzájomnej dôvery. Uplatnenie evolučného hl'adiska ponúka tri hlavné, evolučne vyvinuté mechanizmy (vzájomnej) pomoci a kooperácie: (1) príbuzenský altruizmus ${ }^{33}$, t.j. pomáhanie tým, s ktorými máme najviac spoločných génov, predovšetkým najbližším príbuzným, (2) recipročný altruizmus ${ }^{34}$, t.j. nepríbuzenská pomoc, ktorá predpokladá v budúcnosti protislužbu a (3) reputáciu ${ }^{35}$, ktorá zvyšuje atraktívnost' l’udí, ktorí sú spol'ahliví a dodržiavajú svoje záväzky v tom zmysle, že s nimi iní kooperátori radi kooperujú.

Dnešní l’udia sú teda adaptovaní na určitú mieru kooperatívneho správania a zároveň

\footnotetext{
${ }^{31}$ Tamtiež, s. 131.

${ }^{32}$ De Waal (2006b, s. 206).

${ }^{33}$ Hamilton (1964).

${ }^{34}$ Trivers (1971).

${ }^{35}$ Frank (1990).
} 
mimoriadne citliví na rozpoznávanie a netolerovanie takých prejavov správania, ktoré sa snažia kooperáciu iných zneužit'. Ďalším dôležitým nástrojom ovplyvňujúcim mieru sociálnej dôvery, sú normy, ktoré explicitne stanovujú pravidlá kooperácie a reciprocity a zároveň znižujú riziko ublíženia a podvodu, v dôsledku toho, že obsahujú aj sankčnú stránku.

Dlhodobo kooperovat' je možné len vtedy, ak prevažná väčšina ostatných l'udí tiež kooperuje, napriek tomu, že krátkodobo môže byt' pre nich výhodnejšie podviest'. A účinná kooperácia prebieha len vtedy, ked' si väčšina l'udí navzájom dôveruje, že budú kooperovat'. V súvislosti s dilemou či kooperovat' alebo podviest' používa Rothstein ${ }^{36}$ pojem „sociálne pasce“, ktorým výstižne vyjadruje logiku toho, že bez dôvery nastane ne-kooperácia, t.j. sociálna pasca sa zaklapne, čo je z dlhodobého hl'adiska pre každého horšie ako keby kooperoval. A ked’že sa l'udské spoločnosti vyznačujú narastajúcou kooperáciou, ktorá je pri súčasnom vysokom stupni del'by práce nevyhnutná, musí medzi interagujúcmi jedincami existovat' aj pomerne vysoký stupeň sociálnej dôvery ${ }^{37}$.

Na jednej strane sa predpokladá, že participácia v združeniach vedie k vytváraniu nielen väčšej špecifickej, ale aj všeobecnej sociálnej dôvery a tá následne zvyšuje vel'kost' sociálneho kapitálu. Takéto stanovisko zastáva napr. Putnam ${ }^{38}$, ked' tvrdí, že časté interakcie medzi jedincami v rámci sociálnych sietí, podporujú vzájomnú reciprocitu a dôveryhodnost' a zároveň facilitujú klebetenie, čo je významný nástroj pre kultivovanie reputácie. Zároveň rozlišuje špecifickú reciprocitu, v rámci ktorej si l'udia priamo navzájom oplácajú svoje služby od generalizovanej reciprocity, kedy jeden človek vykoná jednostranne niečo pre iného, pričom verí, že v prípade potreby zase jemu niekto tretí poskytne službu. V evolučnej biológii sa namiesto generalizovanej reciprocity používa pojem nepriama reciprocita (pozri napr. Alexander ${ }^{39}$ ), označujúci vzájomnú pomoc v rámci skupiny, ktorá je v individuálnom záujme každého jej člena. Nepriama reciprocita sa šíri aj vd’aka tomu, že ak členovia skupiny vnímajú, že sa niekto správa altruisticky, aj oni sa k nemu budú správat' altruisticky, pretože bude mat' dobrú reputáciu. Dôvera sa teda takýmto spôsobom vytvára a postupuje zdola nahor. A ked’že sú l’udia zväčša členmi viacerých skupín, môže vd’aka šíreniu informácií o ne/dôveryhodných osobách dochádzat' k vytváraniu širokej siete l'udí, na ktorých je možné sa v rôznych situáciách obrátit'. Takýmto spôsobom sa zároveň dôvera medzi členmi združenia rozširuje aj na osoby, nepatriace do danej lokálnej skupiny. Osobná skúsenost' výrazne vplýva na naše očakávania a preto sa možno spol’ahlivo domnievat', že priamo úmerne počtu dôveryhodných l'udí, s ktorými l’udia vstúpia do interakcií rastie aj miera ich

\footnotetext{
${ }^{36}$ Rothstein (2005).

${ }^{37}$ Zdôrazňovanie úlohy sociálnej dôvery pri zvyšovaní kooperácie neznamená, že medzi jedincami, či záujmovými skupinami nedochádza aj ku konfliktom. Avšak aj na ich riešenie je dôvera nevyhnutná. Bez nej by hrozilo, že žiadna zo strán konfliktu by neustúpila . T.j. pre konštruktívne riešenie konfliktu je nevyhnutná základná dôvera, že zúčastnené strany sa budú snažit' najskôr dospiet' k vzájomne akceptovatel'ným návrhom a potom ich aj dodržiavat'.

${ }^{38}$ Putnam (2000).

${ }^{39}$ Alexander (1987).
} 
všeobecnej dôvery k neznámym l'ud’om $\left(\right.$ Popper $\left.^{40}\right)$. Zároveň možno v takýchto skupinách vytvárat' neformálne sociálne normy a účinne kontrolovat' ich dodržiavanie.

Na strane druhej sa predpokladá, že sociálna dôvera sa buduje zhora nadol. Aj ked' viaceré výskumy tento predpoklad čiastočne potvrdzujú, výhrady voči nemu som formuloval $\mathrm{v}$ príspevku pojednávajúcom o sociálnej dôvere ${ }^{41}$. V ňom argumentujem, že zhora nadol sa šíri skôr nedôvera, čo je dané tým, že mnohí vysoko postavení úradníci a funkcionári pri podozrení na rôzne korupčné aktivity sa nikdy neodvolávajú na morálku, ale len na právo. Ich právnici potom, zväčša úspešne, hl’adajú v zákonoch všetky medzery. Zneužívatelia moci zostávajú právne nevinní, aj ked’ ich väčšina populácie morálne odsudzuje. Takéto praktiky spôsobujú pokles sociálnej dôvery v spoločnosti.

Špecifická dôvera vzniká v rámci konkrétnych vzt’ahov, ktoré sa v drvivej väčšine vytvárajú najprv na úrovni najbližšej rodiny a postupne sa rozširuje na d’alšie okolie. Jedinec, ktorý vyrastá v prostredí dôvery bude mat' tendenciu viac dôverovat' aj l'ud'om, s ktorými sa stretne prvý krát, ako jedinec vyrastajúci v prostredí vysokej vzájomnej nedôvery. To je d’alší protiargument voči predstave, že všeobecná sociálna dôvera je nezávislá na špecifickej dôvere, či dokonca že by ju mohla predchádzat'. Podobne normy z historického pohl'adu vznikali najprv v malých skupinách lovcov-zberačov a až v ovel'a neskoršom období boli mnohé z nich nahradené formálnymi zákonmi. Všetky tieto skutočnosti nasvedčujú tomu, že špecifická dôvera posilňovaná neformálnymi sociálnymi normami bola nevyhnutným predpokladom vzniku všeobecnej sociálnej dôvery ${ }^{42}$.

Okrem sociálneho kapitálu prispieva k zväčšovaniu sociálnej dôvery aj morálny kapitál. Ten charakterizuje Haidt ako atribút spoločenského systému, predstavujúci vnútorne previazané

„súbory hodnôt, cností, noriem, zvyklostí, identít, inštitúcií a technológií, ktoré sa dobre doplňujú s evolučne vytvorenými psychologickými mechanizmami a vd’aka tomu komunite dovol'ujú potlačovat' alebo regulovat' sebectvo a umožňovat' spoluprácu“. ${ }^{43}$

Podstatná čast' tohto morálneho kapitálu je zachytená v etických či morálnych systémoch spoločnosti. Oslabovanie sociálnych a morálnych noriem a etických systémov (Fukuyama ${ }^{44}$, Bauman $^{45}$, Fabio $\left.{ }^{46}\right)$, detradicionalizované spôsoby života $\left(\right.$ Beck $\left.^{47}\right)$, morálny relativizmus

\footnotetext{
${ }^{40}$ Popper (2013).

${ }^{41}$ Tamtiež.

${ }^{42}$ Tamtiež.

${ }^{43}$ Haidt (2013, s. 352).

${ }^{44}$ Fukuyama (2006).

${ }^{45}$ Bauman (2006).

${ }^{46}$ Fabio (2009).

${ }^{47}$ Beck (1992).
} 
$\left(\right.$ Plummer $\left.^{48}\right)$ môžu mat' teda zásadný negatívny dopad na zhoršovanie sociálnej dôvery.

\section{Záver}

Príspevok sa snažil poskytnút' kompaktný pohl'ad na vzt’ahy medzi normami a vzájomnou dôverou. Najprv poukázal na problematickost' operacionalizácie základných druhov noriem a navrhol trojdimenzionálny model diferencujúci medzi sociálnymi a morálnymi normami. Zmysel tohto odlíšenia spočíva v tom, že aj ked’ niektoré morálne normy môžu byt' kultúrne špecifické, porušenie toho, čo sa $\mathrm{v}$ danej spoločnosti považuje za súčast' morálky, bude považované za závažnejšie než porušenie iných noriem. Dôležitost' vymedzenia jednotlivých druhov noriem súvisí aj s tým, že morálne normy sa zdajú byt' najviac riadené emóciami, ktoré sa v evolučnej histórií vyvinuli ovel'a skôr než sa mohla l’udská spoločnost' vd’aka jazykovým kompetenciám dohodnút' na špecifických kultúrnych pravidlách. Tieto emócie teda dokázali aj bez l’udského jazyka signalizovat', či je niečo dobré alebo zlé, správne alebo nesprávne a to predovšetkým z pohl'adu ultimátnych ciel'ov, ako je prežitie a rozmnožovanie. Morálne normy sú tiež odolnejšie voči meniacemu sa, či odlišnému sociálnemu a kultúrnemu prostrediu než sociálne normy. Nakoniec chcel príspevok poukázat' na to, aké dôležité miesto zohrávajú sociálne a morálne normy aj v súčasnosti, napriek pokusom o ich diskreditáciu, či substitúciu legislatívnymi normami. Dôsledkom tohto novodobého „sociálneho poriadku“ je obrovská frustrácia, nespokojnost', apatia, časté sú emócie hnevu, pohoršenia, hnusu nad tým, čo sa v spoločnosti deje. V mnohých situáciách a prípadoch l’udia prirodzene „cítia“, čo je spravodlivé a čo nespravodlivé, bez ohl'adu na to, ako sa k tomu postavia právnici obhajujúci mocenské a finančné ,elity“. Pokial' chceme dlhodobo žit’ v uspokojivých sociálnych väzbách podporujúcich kooperáciu, nie je možné ignorovat' poslanie sociálnych a morálnych noriem. Neznevažovanie a neznehodnocovanie morálneho kapitálu by malo byt' v záujme každej spoločnosti, ktorej záleží na zlepšovaní sociálnej dôvery medzi jej členmi.

\section{Literatúra:}

Alexander, R. D. (1987): The Biology of Moral Systems. Aldine de Gruyter, Hawthorne.

Bauman, Z. (2006): Komunita. Hl'adanie bezpečia vo svete bez istôt. Vydavatel'stvo Spolku slovenských spisovatel'ov, s.r.o., Bratislava.

Beck, U. (1992): Risk Society. Towards a New Modernity. Sage publications, London.

Bicchieri, C. (2006): The Grammar of Society. The Nature and Dynamics of Social Norms. Cambrige University Press, Cambridge.

Boehm, Ch. (2002): „Conflict and the Evolution of Social Control.“ In Evolutionary Origins of Morality. Cross-Disciplinary Perspectives, ed. L. D. Katz, Imprint Academic, Thorverton, 2002, s. 79-101.

\footnotetext{
${ }^{48}$ Plummer (2003).
} 
Dubreuil, B. \& Grégoire, J. F. (2013): „Are Moral Norms Distinct from Social Norms?

A Critical Assessment of John Elster and Cristina Bicchieri.“ Theory and Decision 75

(1): 137-152. DOI 10.1007/s11238-012-9342-3.

De Waal, F. (2006a): „The Tower of Morality.“ In Primates and Philosophers. How Morality Evolved, eds. S. Macedo \& J. Ober, Princeton University Press, Princeton, 2006, s. 161181.

De Waal, F. (2006b): Dobráci od př́rody. Academia, Praha.

Fabio, U. D. (2009): Kultura Svobody. Centrum pro studium demokracie a kultury (CDK), Brno.

Fehr, E. \& Gächter, S. (2000): „Fairness and Retaliation: The Economics of Reciprocity.“ The Journal of Economic Perspectives 14 (3): 159-181.

Frank, R. H. (1990): „A Theory of Moral Sentiments.“ In Beyond Self-Interest, ed. J. J. Mansbridge, The University of Chicago Press, Chicago, 1990, s. 71-96.

Fukuyama, F. (2006): Velký rozvrat. Lidská přirozenost a rekonstrukce společenského řádu. Academia, Praha.

Haidt, J. (2013): Morálka lidské mysli. dybbuk, Praha.

Haidt, J. \& Bjorklund, F. (2007): „Social Intuitionists Answer Six Questions about Moral Psychology.“ In Moral Psychology. Vol. 2. The Cognitive Science and Morality: Intuition and Diversity, ed. W. Sinnott-Armstrong, The MIT Press, Cambridge, 2007, s. 181-217.

Haidt, J., Koller, S. \& Dias, M. (1993): „Affect, Culture, and Morality, or Is it Wrong to Eat Your Dog?" Journal of Personality and Social Psychology 65: 613-628.

Hamilton, W. D. (1964): „The Genetical Evolution of Social Behaviour. I, II.“ Journal of Theoretical Biology 7: 1-52.

Hauser, M. D. (2006): Moral Minds. HarperCollins Publishers, New York.

Knauft, B. M. (2000): „Symbols, Sex and Sociality in the Evolution of Human Morality.“ In Evolutionary Origins of Morality. Cross-Disciplinary Perspectives, ed. Leonard D. Katz, Imprint Academic, Thorverton, 2000, s. 130-139.

Mallon, R. \& Nichols, S. (2010): „Rules.“ In The Moral Psychology Handbook, ed. J. M. Doris, Oxford University Press, Oxford, 2010, s. 297-320.

Milgram, S. (1963): „Behavioral Study of Obedience.“ Journal of Abnormal and Social Psychology 67: 371-378.

Nucci, L. P. (2001): Education in the Moral Domain. Cambridge University Press, Cambridge.

Plummer, K. (2003): Intimate Citizenship. University of Washington Press, Seatle.

Popper, M. (2013): „Social Trust, Norms and Morality.“ Human Affairs 23 (3): 443-457.

Prinz, J. J. (2007): „Is Morality Innate?“ In Moral Psychology, Volume 1: The Evolution of Morality: Adaptations and Innateness, ed. W. Sinnott-Armstrong, The MIT Press, Cambridge, 2007, s. 367-406. 
Putnam, R. D. (2000): Bowling Alone. The Collapse and Revival of American Community. Simon \& Schuster, New York.

Rothstein, B. (2005): Social Traps and the Problem of Trust. Cambridge University Press, Cambridge.

Rozin, P., Lowery, L., Imada, S. \& Haidt, J. (1999): „The CAD Triad Hypothesis: A Mapping Between Three Moral Emotions (Contempt, Anger, Disgust) and Three Moral Codes (Community, Autonomy, Divinity).“ Journal of Personality and Social Psychology 76 (4): 574-586.

Trivers, R. L. (1971): „The Evolution of Reciprocal Altruism.“ Quarterly Review of Biology (46): $35-57$.

Turiel, E. (2002): The Culture of Morality: Social Developmnent, context and conflict. Cambridge University Press, Cambridge.

Turiel, E. (2006): „The Multiplicity of Social Norms: the Case for Psychological Constructivism and Social Epistemologies.“ In Norms in Human Development eds. L. Smith \& J. Vonèche, Cambridge University Press, Cambridge, 2006, s. 189-207.

Ullmann-Margalit, E. (1997): The Emergence of Norms. Oxford University Press, Oxford. Wright, R. (2006): „The Uses of Anthropomorfism.“ In Primates and Philosophers. How Morality Evolved, eds. S. Macedo \& J. Ober, Princeton University Press, Princeton, 2006, s. 83-97. 